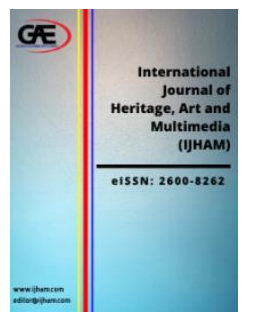

\author{
INTERNATIONAL JOURNAL OF \\ HERITAGE, ART AND MULTIMEDIA \\ (IJHAM) \\ www.ijham.com
}

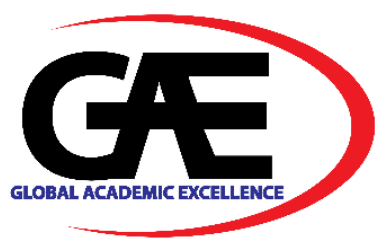

\title{
ANALISIS KEROSAKAN KUBU PEPERANGAN TINGGALAN BRITISH PADA ZAMAN PEPERANGAN DUNIA KE II DI KAMPUNG GER, BACHOK, KELANTAN
}

\section{DAMAGE ANALYSIS OF BRITISH WAR PILLBOX IN KAMPUNG GER BACHOK, KELANTAN}

Nur Athmar Hashim ${ }^{1 *}$, Siti Aisyah Muhammad ${ }^{2}$, Tengku Fauzan Tengku Anuar ${ }^{3}$, Mohd Mokhtar Saidin $^{4}$, Suresh Narayanen ${ }^{5}$, Nur Farhana Shuhaimi ${ }^{6}$

$1 \quad$ Fakulti Teknologi Kreatif dan Warisan, Universiti Malaysia Kelantan, Malaysia dan Pusat Penyelidikan Arkeologi Global, Universiti Sains Malaysia, Malaysia

Email: athmar.h@umk.edu.my

2 Fakulti Senibina dan Ekistik, Universiti Malaysia Kelantan, Malaysia

Email: aisyah@umk.edu.my

3 Fakulti Teknologi Kreatif dan Warisan, Universiti Malaysia Kelantan, Malaysia dan Pusat Penyelidikan Kemiskinan dan Pengurusan (INSPEK), Universiti Malaysia Kelantan, Malaysia

Email: tengkufauzan@umk.edu.my

$4 \quad$ Pusat Penyelidikan Arkeologi Global, Universiti Sains Malaysia, Malaysia

Email: mmokh@usm.my

$5 \quad$ Pusat Penyelidikan Arkeologi Global, Universiti Sains Malaysia, Malaysia

Email: sureshnarayanen@usm.my

$6 \quad$ Fakulti Teknologi Kreatif dan Warisan, Universiti Malaysia Kelantan, Malaysia

Email: hannashuhaimi969@gmail.com

* Corresponding Author

Article Info:

Article history:

Received date: 17.06 .2021

Revised date: 15.07. 2021

Accepted date: 30.07 .2021

Published date: 01.09.2021
Abstrak:

Kubu merupakan sebuah tempat perlindungan atau pertahanan yang dibina khusus bagi mempertahankan sesuatu kawasan daripada serangan pihak musuh. Pihak tentera akan mencari tempat perlindungan atau berkubu untuk mempertahankan kawasan atau petempatan daripada serangan musuh dari pelbagai arah seperti serangan udara dan serangan darat dengan membina sendiri samada dengan menggali lubang, membuat dinding besi, dinding pasir atau konkrit bergantung kepada tujuan dan jangkamasa penggunaannya. Kubu peperangan juga memainkan peranan penting dalam strategi pertahanan statik 


\section{To cite this document:}

Hashim, N. A, Muhammad, S. A., Anuar, T. F. T., Saidin, M. M., Narayanen, S., \& Shuhaimi, N. F. (2021). Analisis Kerosakan Kubu Peperangan Tinggalan British Pada Zaman Peperangan Dunia Ke II Di Kampung Ger, Bachok, Kelantan. International Journal of Heritage, Art and Multimedia, 4 (14), 01-12.

DOI: 10.35631/IJHAM.414001.

This work is licensed under $\underline{\mathrm{CC} B Y} 4.0$

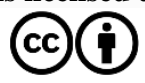

bagi setiap pasukan ketenteraan untuk mematahkan serangan musuh. Walaubagaimanapun, pada hari ini kubu peperangan yang terdapat di Kampung Ger, Bachok yang berkoordinat N6.001235 ${ }^{\circ}$ E102.429801 ${ }^{\circ}$ telah mengalami beberapa kerosakan yang lama kelamaan akan menyebabkan berlakunya kemusnahan. Penyelidikan yang menggunakan kaedah yang bersistematik seperti catatan, pemerhatian, dan pengambilan gambar telah mengenalpasti jenis-jenis kerosakan yang telah dialami oleh monumen ini. Melalui analisis XRF juga dapat membuktikan bahawa kandungan mineral yang terdapat dalam binaan kubu ini juga telah mempengaruhi kerosakan.

\section{Kata Kunci:}

Jenis-Jenis Kerosakan, Kubu Peperangan, Kampung Ger, Bachok, Analisis XRF

\begin{abstract}
:
A fort is a shelter or defense built specifically to defend an area from enemy attacks. The military will seek shelter or fortifications to defend areas or settlements from enemy attacks from various directions such as air and ground attacks by building their own either by digging holes, making iron walls, sand walls, or concrete depending on the purpose and duration of use. War forts also play an important role in the static defense strategy of each military force to break enemy attacks. However, today the war fort found in Kampung Ger, Bachok with coordinates N6.001235 ${ }^{\circ}$ E102.429801 ${ }^{\circ}$ has suffered some damage that over time will cause destruction. Research using systematic methods such as notes, observations, and photographs has identified the types of damage that have been suffered by these monuments. XRF analysis can also prove that the mineral content found in the construction of this fort has also affected the damage.
\end{abstract}

Keywords:

Types Of Damage, War Fort, Kampung Ger, Bachok, Analysis XRF

\section{Pengenalan}

Negeri Kelantan sinonim dengan peninggalan kubu peperangan di sekitar pantai. Kubu peperangan yang berada di perairan Kelantan dipercayai mempunyai lebih 30 buah kubu peperangan yang dibina oleh pihak Bristish semasa Perang Dunia Kedua (DJ Dolasoh, 2015). Walaubagaimanapun kubu peperangan yang terdapat di Kelantan tidak dipelihara dan dipulihara dengan baik sedangkan ianya mempunyai daya tarikan ekonomi dari segi nilai sejarahnya yang tinggi. Kubu peperangan tinggalan British ini kebanyakannya mengalami deteriorasi akibat hakisan pantai dan sebahagiannya telah ditenggelami air laut (Indrajaya, 2014). Di Bachok, kebanyakan kubu dibina di persisiran pantai dipercayai kerana Jepun akan menggunakan arah laut untuk menawan Kelantan (Salleh Arkib, 2013). Artikel ini memberikan fokus kepada satu kawasan yang mempunyai kubu peperangan iaitu di Kampung Ger. Koordinat kubu di Kampung Ger adalah N6.001235 E102.429801 (Rajah 1). Kedudukan kubu kubu di Kampung Ger berada di kawasan daratan, namun berada di kawasan pantai. 


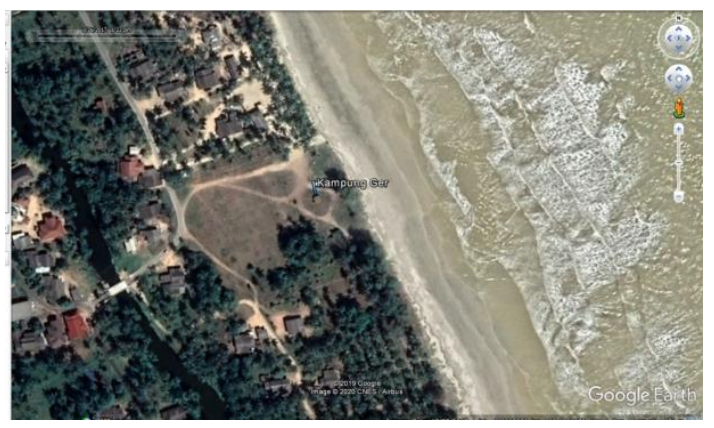

\section{Rajah 1: Lokasi Kubu di Kampung Ger}

\section{Kajian Terdahulu}

Terdapat lebih kurang 30 buah kubu yang telah dibina oleh pihak British di Kelantan bertujuan untuk dijadikan sebagai tembok pertahan dari pencerobohan Jepun (Asnah Hanim, 2010). Kebanyakan kubu yang telah dibina ini mempunyai bentuk segi empat dan mempunyai lubanglubang kecil yang dikatakan sebagai tempat untuk melepaskan tembakan. Kebanyakan kubu yang telah dibina ini dianggarkan berukuran tiga meter tinggi dan enam meter lebar (DJ Dolasoh, 2015). Walaubagaimanapun, sebahagian daripada kubu ini telah musnah akibat daripada hakisan ombak (Rajah 2).

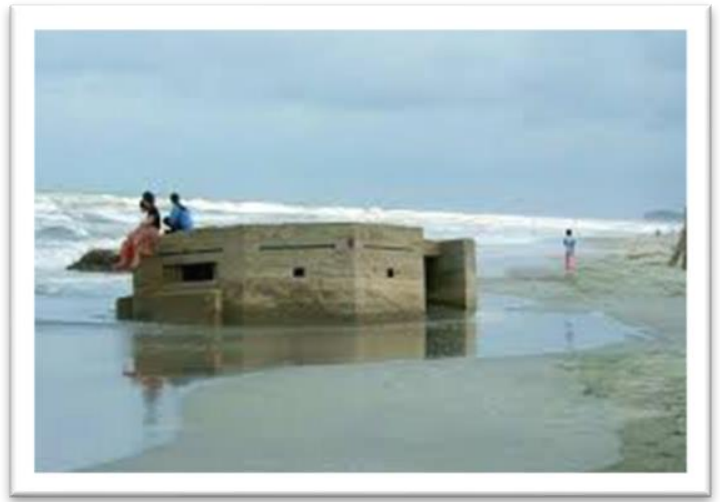

\section{Rajah 2: Kubu Peperangan Yang Terdapat Di Pantai Bachok.}

Sumber : Artikel Daripada Lokman Ismail (2018) Berjudul Kubu Peperangan Sejarah Perang Dunia Kedua. Dicapai Pada September 16, 2019 Daripada http://bicaramentari.blogspot.com//2018/10/bgq.html?m=1

Setiap kubu peperangan yang dibina mempunyai perbezaan dari segi tinggi dan rendah. Selain itu, pembinaan kubu juga bergantung kepada kedudukan geografi dan keluasan kawasan pembinaan. Selain itu, pembinaan kubu juga menitikberatkan jenis senjata yang digunakan dalam menghadapi serangan musuh (Freddie Aziz Jasbindar, 2019). Kubu peperangan yang dibina oleh pihak British adalah berbentuk oktagon dan dibina daripada pasir sungai, kerawat besi, dan konkrit bagi memuatkan askar Gurka dan Punjabi dalam memepertahankan serangan askar Jepun (Abdul Rahman, 2016). Pada tahun 1939-1941, pihak British telah membina kubu yang kukuh dan kuat sepanjang jalan yang berkemungkinan menjadi tumpuan tentera Jepun untuk membuat serangan (Raj, 2007). 
Kubu yang terdapat di Pantai Sabak merupakan kubu yang terkuat antara kubu-kubu lain yang dibina. Hal ini kerana kubu tersebut dibina untuk mempertahankan lapangan terbang Pengkalan Chepa dimana ianya juga merupakan penempatan logistik tentera British yang penting (Mohd Radzi, 2009). Selain itu, kubu tersebut dibina di Pantai Sabak kerana lokasi yang strategik berhampiran dengan Thailand dan Vietnam (Nik Mohamed Nik Mohd Salleh,2006). Walaubagaimanapun, kubu ini sebenarnya telah musnah akibat daripada hakisan pantai (Rajah $3)$.

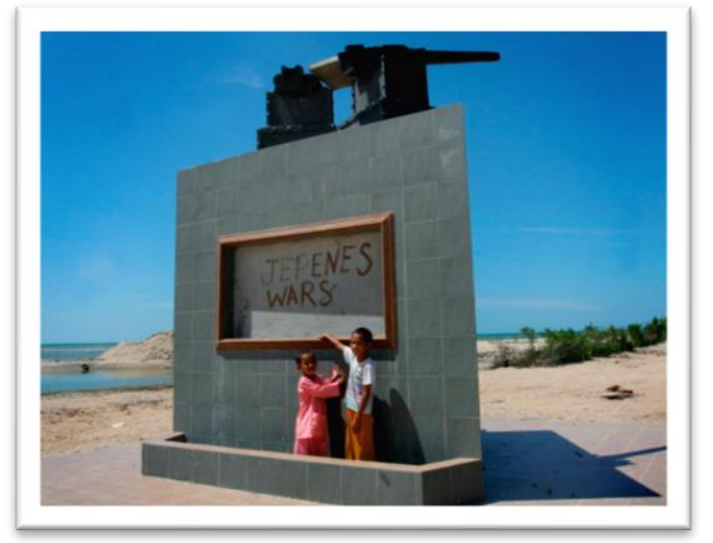

\section{Rajah 3: Tugu Peringatan Di Pantai Sabak}

Sumber: Artikel Kelab Pencinta Sejarah Kelantan (2015) Bertajuk Pantai Sabak Terakam Dalam World War 2. Dicapai Pada Februari 21, 2019 Daripada https://sejarahkelantan.wordpress.com/tag/British/

Dalam perang dunia kedua yang berlaku, kubu-kubu telah dibina dengan lokasi yang strategik terutamanya di persisiran pantai utara iaitu dari Bachok ke Tumpat dimana lokasi tersebut menghala ke Laut China Selatan (J. Jokilehto,1990). Anggaran kubu yang terdapat di Kelantan bermula dari Kota Bharu sehingga ke Bachok adalah sebanyak 30 buah kubu. Namun kebanyakannya telah hilang lokasi sebenar akibat daripada hakisan pasir pantai yang berlaku saban tahun (Rajah 4) (Salleh Arkib, 2013)

\section{Kaedah Penyelidikan}

Bagi sesebuah proses penyelidikan, kajian terdahulu memainkan peranan penting bagi pengumpulan data-data yang telah diperoleh daripada pengkaji terdahulu untuk menyokong pengkajian yang akan dijalankan. Selain itu, kajian terdahulu juga bertujuan untuk memberikan penjelasan mengenai kajian yang dijalankan berdasarkan maklumat yang tepat. Survei lapangan dilaksanakan di kubu ini bertujuan untuk mendapatkan gambaran awal lokasi. Berdasarkan survei ini mendapati bahawa keadaan kubu-kubu ini adalah terbiar (Rajah 5). 


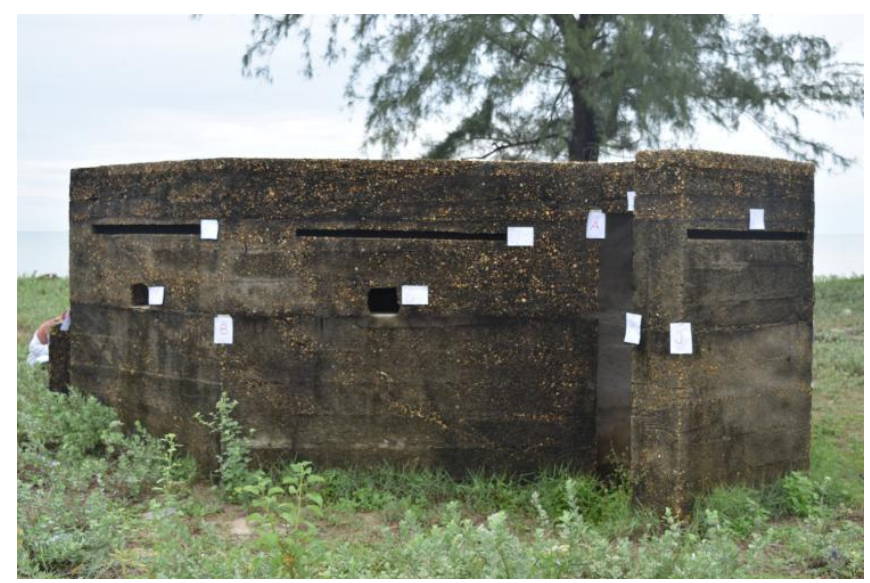

Rajah 5: Keadaan Kubu Kampung Ger, Bachok

Melalui pemerhatian yang dijalankan mendapati bahawa lokasi kubu di Kampung Ger adalah terletak berdekatan dengan chalet penduduk setempat. Namun begitu, keadaan yang sunyi menyebabkan persekitaran menjadi tidak terurus dan keadaan pantai yang dicemari oleh sampah sarap juga menjadikan kawasan kubu ini tidak dikunjungi oleh pelancong (Rajah 6).

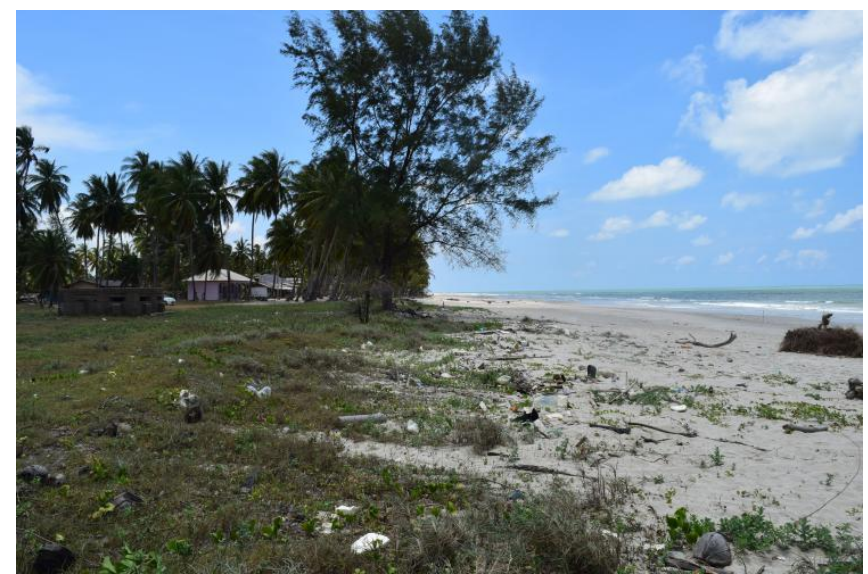

Rajah 6: Persekitaran di Kubu Kampung Ger, Bachok

\section{Hasil Kajian}

Pembinaan kubu-kubu peperangan di sekitar persisiran pantai ini bertujuan untuk mempertahankan negeri Kelantan daripada serangan tentera Jepun dari arah Laut China Selatan pada 7 Disember 1941. Kubu-kubu peperangan di sekitar kawasan Bachok khususnya di Kampung Ger menggunakan material yang sama dalam pembinaanya. Bentuk kubu peperangan tersebut seperti bulatan tapak kuda tetapi bersegi 9 manakala atap serta dindingnya pula diperbuat daripada campuran simen, pasir dan batu sungai serta kerawat besi dengan ketebalan dianggarkan 9 inci (Hamzah h.d, 2007). Penggunaan pasir dan batu sungai sebagai bahan utama dalam pembinaan kubu peperangan tersebut disebabkan ianya tahan lasak dan sukar mengalami kerosakan. Namun, setiap sebuah kubu tersebut terdapat sedikit perbezaan seperti ukuran saiz tinggi rendah dan petak-petak dinding di bahagian dalamnya seolah-olah seperti dinding bilik dalam sebuah rumah (Holmes 2015). Perbezaan ini mengikut keperluan 
Volume 4 Issue 14 (September 2021) PP. 01-12 DOI 10.35631/IJHAM.414001

dan kegunaan senjata api yang berbeza-beza seperti mesin-gan dan senapang jenis MK-4 atau MK-5 antara suatu tempat dengan tempat yang lain (Nik Mohamed, 1995). Seterusnya, jumlah askar yang ditugaskan di dalam kubu tersebut juga berbeza. Mengikut keterangan seorang pegawai tentera Malaysia, tiap-tiap sebuah kubu itu biasanya ditempatkan satu pasukan yang mengandungi antara 5 hingga 10 orang askar (Salleh Mohd Akib, 2013). Keadaan kubu peperangan di Kampung Ger pada hari ini masih lagi dalam keadaan baik cuma terdapat sedikit kerosakan seperti keretakan manakala kubu peperangan (Rajah 7)

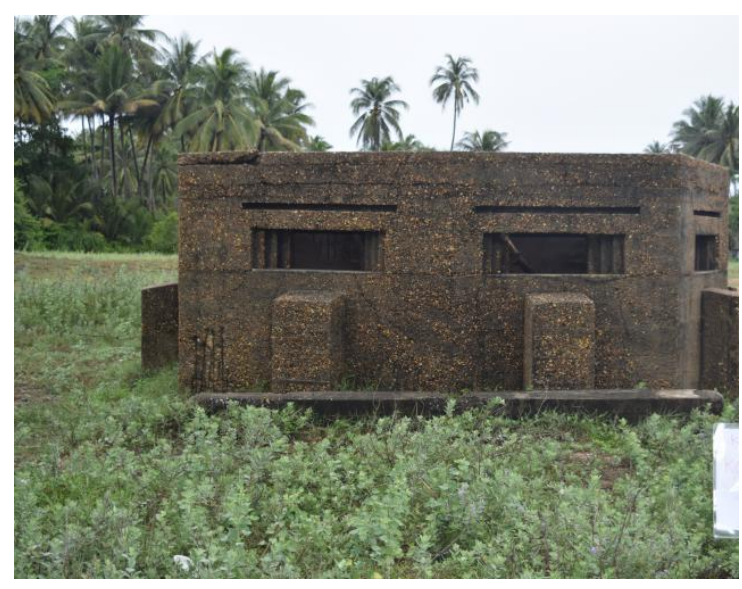

\section{Rajah 7: Keadaan Terkini Kubu Peperangan di Kampung Ger}

Selain itu, penggunaan kompas geologi juga membantu kajian ini bagi menganalisis kedudukan kubu ini daripada pantai (Rajah 8). Selain itu juga, pemerhatian melalui perubahan pasir di kawasan pantai juga merupakan satu kaedah yang digunakan untuk melihat perubahan yang dialami secara semulajadi. Perubahan warna pasir telah dilabelkan dengan Tahap 1, 2 , 3 dan juga 4 (Rajah 9). Ia adalah bertujuan untuk melihat sejauh mana perubahan monumen ini disebabkan oleh pemendapan dan timbunan pasir yang semakin tinggi. Pemetaan secara saintifik dengan menggunakan pro-map juga adalah satu kaedah yang digunakan untuk melihat tahap kedudukan kubu dari pantai. Dengan mencari sekurang-kurangnya empat titik koordinat, analisis akan dijalankan dengan menghasilkan keratan rentas (Rajah 10).

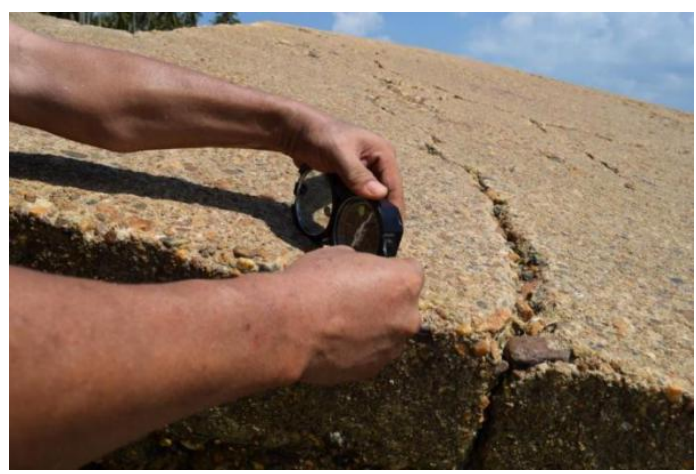

Rajah 8: Penggunaan Kompas Geologi

(Sumber : Nur Athmar Hashim et al 2020 IOP Conf. Ser.: Earth Environ. Sci. 549 012082)

Copyright $\odot$ GLOBAL ACADEMIC EXCELLENCE (M) SDN BHD - All rights reserved 


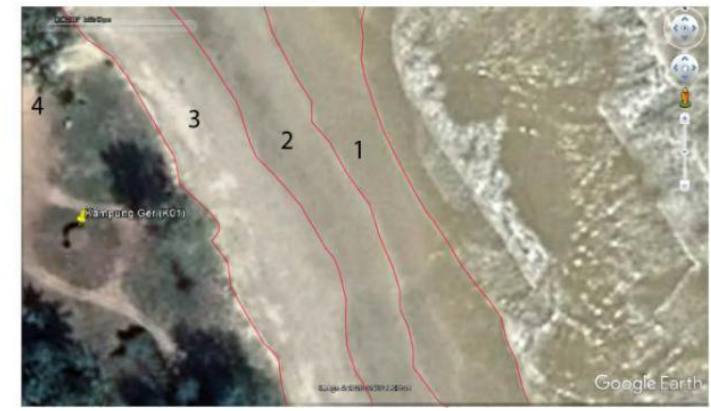

\section{Rajah 9: Pemerhatian Berdasarkan Kepada Perubahan Pasir}

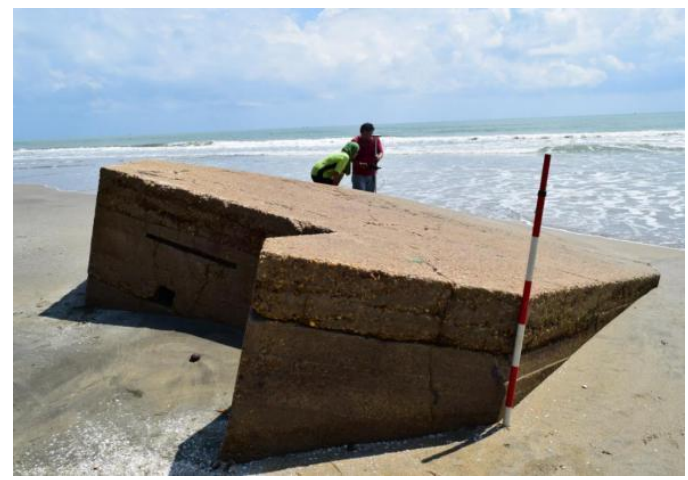

\section{Rajah 10: Penentuan Titik Koordinat}

(Sumber : Nur Athmar Hashim et al 2020 IOP Conf. Ser.: Earth Environ. Sci. 549 012082)

\section{Hasil Kajian}

Berdasarkan keratan rentas (Rajah 11) mendapati bahawa lokasi kubu peperangan di Kampung Ger masih terletak di bahagian daratan dan jaraknya dengan persisir pantai atau gigi air dianggarkan sekitar 60-70 meter iaitu di teres yang ke-4 dengan ketinggian 10.7 meter dari arah pantai. Apabila air laut pasang ombak akan mencecah kedudukan kubu peperangan tersebut dan mengakibatkan pasir-pasir pantai menimbusinya sekaligus menyebabkan proses mendapan berlaku. Proses pemendapan ini menyebabkan lama kelamaan kubu di Kampung Ger ini akan tenggelam di dalam laut dan hal ini menyebabkan satu nilai warisan sejarah akan tinggal sejarah sekiranya usaha untuk pemeliharaan tidak dijalankan. 


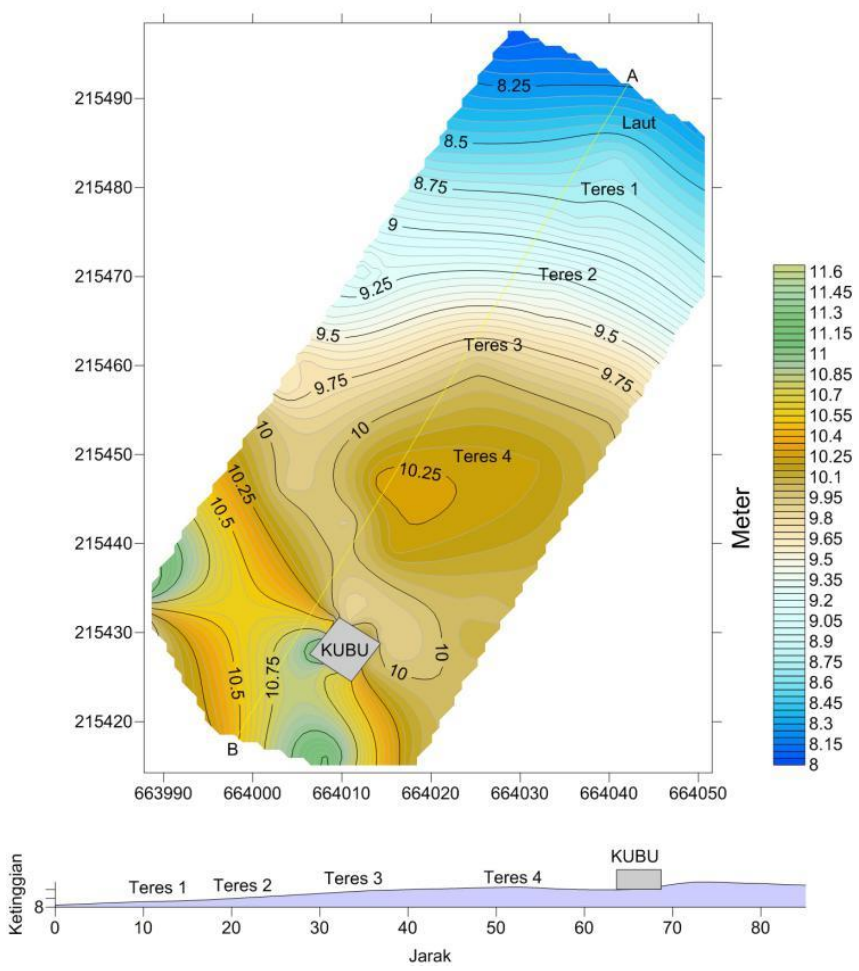

Rajah 8: Keratan Rentas Lokasi Kubu di Kampung Ger dari Pantai

(Sumber: Nur Athmar Hashim et al 2020 IOP Conf. Ser.: Earth Environ. Sci. 549 012082)

Setiap struktur bahagian kubu peperangan ditandakan dengan kod yang tersendiri iaitu A, B, C, D, E, F, G, H, I, J, K. Analisis yang telah dijalankan mendapati bahawa terdapat enam jenis kerosakan yang terdapat pada kedua-dua kubu ini. Berikut merupakan jenis-jenis kerosakan yang terdapat pada struktur kubu peperangan di Kampung Ger dan Kubang Kawah:
[D1] Lumut
[D2] Retak
[D3] Pengaratan
[D4] Pemendapan
[D5] Hakisan
[D6] Serangan anai-anai

Kerosakan-kerosakan tersebut telah menjejaskan struktur kubu peperangan disebabkan ianya tidak dijaga dan dibiarkan tanpa sebarang proses pemuliharaan dan pemeliharaan oleh pihakpihak berwajib. Oleh itu, pengkaji telah mengambil kira beberapa faktor berdasarkan kesesuaian keadaan dan persekitaran lokasi kajian untuk mengenalpasti jenis kerosakan yang berlaku terhadap kubu-kubu peperangan terbabit. Keadaan kerosakan kubu di Kampung Ger adalah seperti di Jadual 1. 
Volume 4 Issue 14 (September 2021) PP. 01-12 DOI 10.35631/IJHAM.414001

\section{Jadual 1: Jenis-Jenis Kerosakan Yang Telah Dikenalpasi Di Kubu Peperangan Di Kampung Ger}

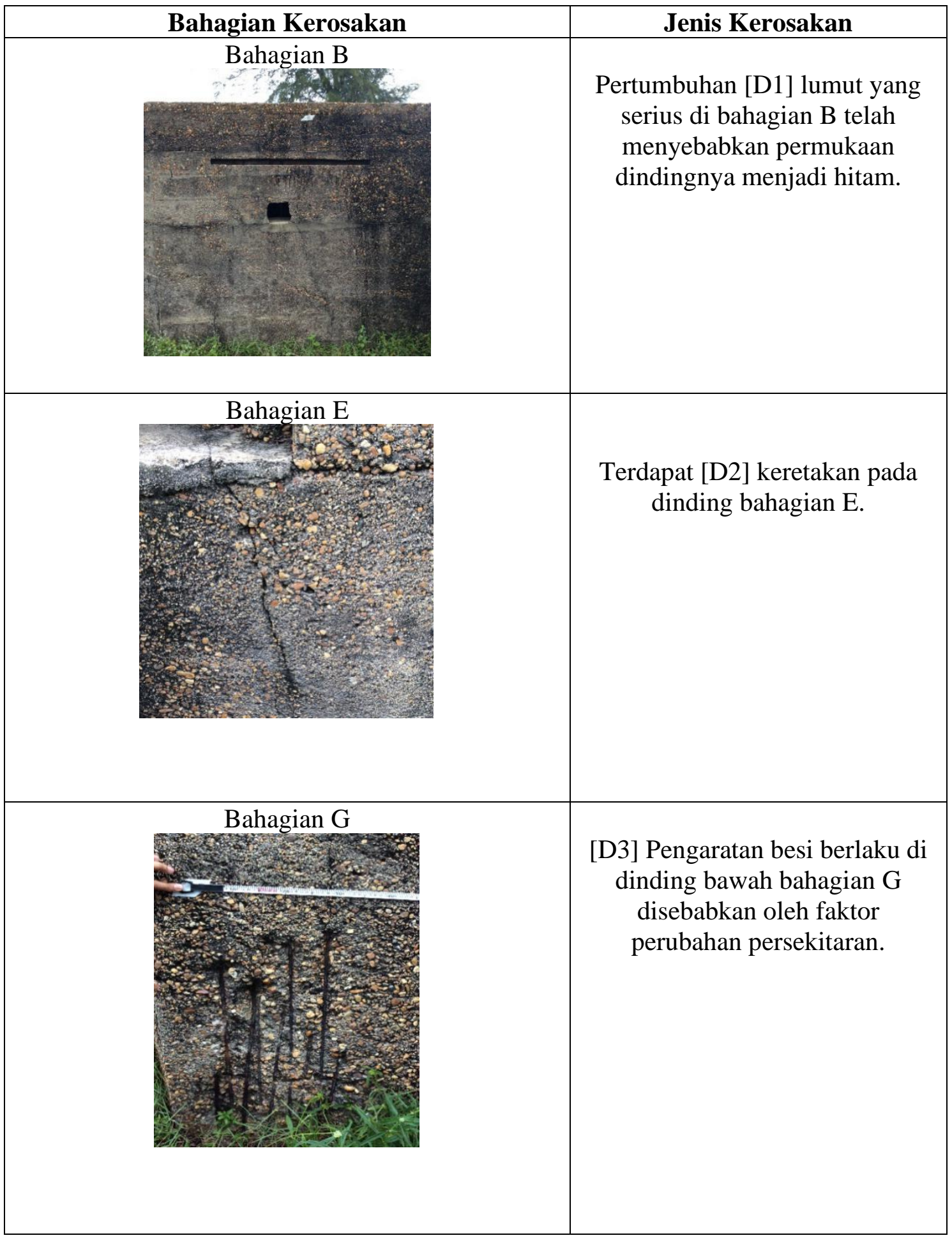




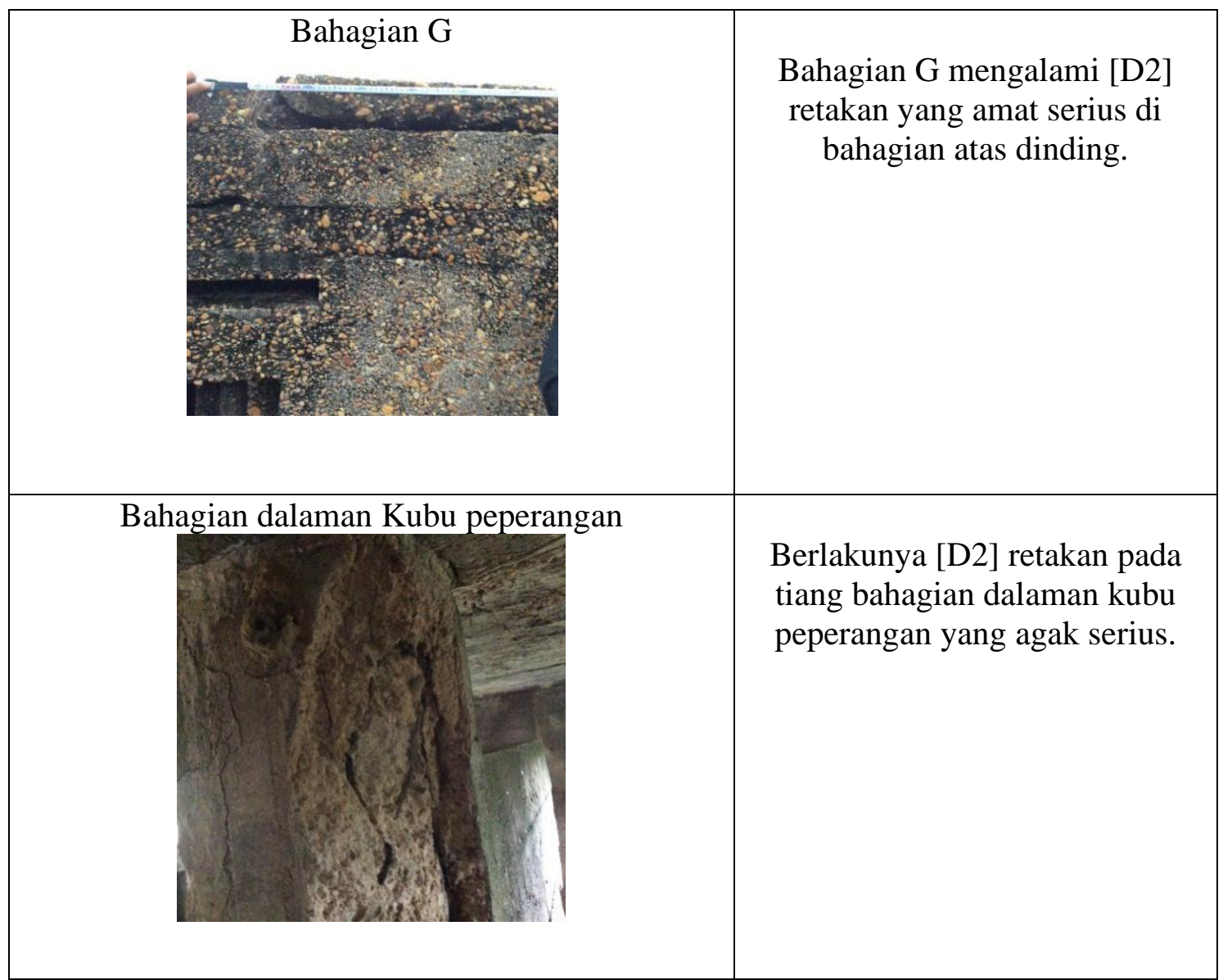

(Sumber: Kajian Penyelidikan)

Berdasarkan Jadual 1, analisis mendapati bahawa Bahagian B telah menunjukkan berlakunya pertumbuhan [D1] lumut yang serius sehingga menyebabkan permukaan dindingnya menjadi hitam. [D1] Lumut merupakan sejenis organisma saprofit atau parasit yang mampu menghakis struktur dinding kubu peperangan apabila asid humik terbentuk semasa proses pertumbuhannya. Pertumbuhan lumut juga disebabkan oleh beberapa faktor utama seperti cahaya, suhu dan kelembapan udara. Kedudukan kubu peperangan yang terletak di persisiran pantai telah menyebabkan pertumbuhan lumut berlaku dengan cepat disebabkan ianya lebih terdedah kepada cahaya, suhu dan kelembapan suhu sekaligus menjejaskan struktur kubu peperangan tersebut. Tambahan lagi, keadaan kubu peperangan yang tidak dijaga mengakibatkan pertumbuhan lumut semakin serius sehingga terhasilnya tompokan hitam yang menyebabkan struktur kubu peperangan menjadi tidak kuat.

Seterusnya, berlaku dua jenis [D2] keretakan pada permukaan dinding bahagian E dan G iaitu keretakan halus dan keretakan kasar. Bahagian E mengalami keretakan halus sepanjang $50 \mathrm{~cm}$ manakala dinding atas bahagian $G$ pula mengalami keretakan kasar sepanjang $73 \mathrm{~cm}$. Hal ini disebabkan berlakunya proses pengecutan dan pengembangan pada struktur kubu peperangan yang terdedah kepada cuaca yang tidak menentu. Selain itu, hakisan juga merupakan salah satu 
Volume 4 Issue 14 (September 2021) PP. 01-12 DOI 10.35631/IJHAM.414001

faktor berlakunya keretekan struktur kubu peperangan disebabkan kedudukannya yang terletak di perisisran pantai.

Selain itu, berlakunya [D3] pengaratan besi pada dinding bawah bahagian G disebabkan adanya kehadiran air dan udara. Kedudukan kubu peperangan yang terletak di persisiran pantai telah menyebabkan berlakunya hakisan yang memusnahkan dinding konkrit sehingga tertimbulnya tetulang keluli. Tetulang keluli yang terdedah kepada udara dan air masin akan mempercepatkan lagi proses pengaratan berlaku dan menyebabkan struktur kubu peperangan menjadi tidak kukuh serta menjadi faktor kepada kerosakan-kerosakan yang lain seperti keretakan. Walaubagaimanapun, proses pengaratan ini mengambil masa yang lama sebelum berlakunya keretakan dan kerosakan yang lain. Retakan (D2) yang teruk pada tiang konkrit bahagian dalaman kubu peperangan menyebabkan tiang ini hampir musnah. Hal ini kerana, kemasukan air laut disertakan angin yang kuat mempengaruhi kerosakan struktur tiang ini. Analisis XRF terhadap kubu di Kampung Ger juga telah dilakukan bagi mendapat keputusan yang saintifik berkaitan dengan kandungan mineral yang terdapat dalam pembinaan kubu ini. Keputusan yang diperoleh menunjukkan terdapat beberapa bahan seperti Silicon oxide $\left(\mathrm{Si}_{2}\right)$, Titanium (IV) oxide $\left(\mathrm{TiO}_{2}\right)$, Aluminium oxide $\left(\mathrm{Al}_{2} \mathrm{O}_{3}\right)$, Iron (111) oxide $\left(\mathrm{Fe}_{2} \mathrm{O}_{3}\right)$, Manganese oxide $(\mathrm{MnO})$, Magnesium oxide $(\mathrm{MgO})$, Calsium oxide $(\mathrm{CaO})$, Natrium oxide $\left(\mathrm{Na}_{2} \mathrm{O}\right)$, Potassium oxide $\left(\mathrm{K}_{2} \mathrm{O}\right)$, dan Phosphorus $(\mathrm{V})$ oxide $\left(\mathrm{P}_{2} \mathrm{O}_{5}\right)$ yang terkandung dalam bahan binaan monumen tersebut. Peratusan bahan tertinggi dalam ketiga-tiga sampel adalah Silicon oxide dengan peratus sebanyak $77.88 \%$. kandungan Silicon oxide yang merupakan salah satu metaloid tetravalen dan banyak terdapat pada bumi dalam bentuk pasir dan tanah liat. Bahan ini sangat penting dalam binaan sebagai racun makhluk perosak. Bahan seterusnya adalah Aluminium oxide yang paling tinggi terkandung dalam sampel iaitu sebanyak $4.14 \%$. Aluminium oxide merupakan bahan yang mempunyai takat lebur yang tinggi dan mampu menjadi pelelas kerana kekerasannya. Bahan seterusnya ialah Iron (1ll) oxide dimana pada sampel iaitu $3.75 \%$. Iron (III) oxide adalah sebatian besi yang teroksida atau proses pengaratan kesan daripada air laut. Hal ini kerana, sampel bagi kubu ini diambil di lokasi kubu yang berada di persisiran pantai.

Hasil analisis mendapati bahawa kebanyakan struktur kubu majoriti telah mengalami kerosakan dan tidak dijaga dengan lebih baik. Kebanyakan struktur ini telah ditinggalkan malah ada di antaranya telah mengalami kerosakan seperti hakisan, pemendapan, pemecahan, vandalisme serta menjadi sarang serangga. Hal ini menyebabkan monumen warisan ini lama kelamaan hanya tinggal dalam lipatan sejarah.Melalui analisis XRF terhadap tiga struktur juga menggambarkan bahawa kerosakan struktur juga disebabkan pengaruh semula jadi seperti kandungan garam yang berlebihan yang menyebabkan pengaratan dan pemecahan pada struktur.

\section{Penghargaan}

Artikel ini adalah ditulis sebagai penghargaan ke atas Allayarham Dr.Jeffrey Abdullah dari Pusat Penyelidikan Arkeologi, Universiti Sains Malaysia dan memenuhi syarat Doktor Falsafah (Phd). Penghargaan juga terhadap geran FRGS 2020 yang bertajuk Pencirian Struktur Binaan Kubu Peperangan British Di Negeri Kelantan Untuk Tujuan Konservasi. 


\section{Rujukan}

Abdul Rahman Hj. Abdullah (2016). Gerakan Penjajahan Dan Anti-Penjajahan Tanah Melayu 1511 - 1957. Shah Alam, Selangor: Grupbuku Karangkraf

Asnah Hanim Mahmood (2010). Sejarah kubu tentera British. Utusan Malaysia. Diambil daripada

http://ww1.utusan.com.my/utusan/info.asp?y=2010\&dt=1014\&sec=Timur\&pg=wt_01 .htm

DJ Dolasoh 2015 Kubu Lama Tarikan Pelancong in rencana@hmetro.com.my. Retrieved on 15th January 2020

Hamzah h.d (2007). Sejarah kubu di Malaysia dan perkembangannya. Majalah Perajurit Edisi Januari 2007. Diambil daripada http://min-def.blogspot.my/2008/08/sejarah-kubu-dimalaysia-dan.html

Holmes R (2015). World War II, The Definitive Visual Guide. London: Darling Kindersley

Indrajaya Abdullah (2014). Ringkasan Sejarah Tentera Anti-Jepun Rakyat Malaya. Petaling Jaya, Malaysia: Strategic Information and Research Development Centre

J.Jokilehto (1990). Definition Of Cultural Heritage, References to Documents In History. ICCROM

Kelab Pencinta Sejarah Kelantan (2015), Pantai Sabak Terakam Dalam World War 2 in https://sejarahkelantan.wordpress.com/tag/British/. Retrieved on 21 February 2019.

Mohd Radzi Abd Hamid (2009). Pendudukan Jepun Di Tanah Melayu Dan Borneo. Ampang, Selangor Darul Ehsan: Dawana Sdn. Bhd.

Nur Athmar Hashim, Tengku Fauzan Tengku Anuar, Siti Aishah Muhammad, Suresh Narayanen, Mokhtar Saidin, Nawwal Abdul Kadir, Nur Farhana Shuhaimi, dan Adam Mad Zain (2020), Analysis of the Causes of Destruction of Two British Pillboxes in Bachok, Kelantan.IOP Conf. Ser.: Earth Environ. Sci. 549012082

Nik Mohamed Nik Mohd Salleh 2006 Peperangan Dunia Di Kelantan: Disember 1941(Perbadanan Muzium Negeri Kelantan)

Nik Mohamed Nik Mohd. Salleh (1995). Warisan Kelantan. Kota Bharu, Kelantan: Perbadanan Muzium Negeri Kelantan.

Raj J.J (JR) 2007 The Struggle For Malaysian Independence (MPH Publishing, Petaling Jaya, Malaysia)

Salleh Mohd Akib 2013 Kesan-kesan Tinggalan Perancangan Dunia Kedua 1941-1945 Di Kelantan (Perbadanan Muzium Negeri Kelantan)

Salleh Mohd Akib 2013 Kubu Kebal British (The British Pillbox) (Perbadanan Muzium Negeri Kelantan) 